\title{
STATYSTYCZNE BEZPIECZEŃSTWO W POLSCE
}

Ministerstwo Spraw Wewnętrznych w sierpniu 2013 r. opublikowało kolejny raport o stanie bezpieczeństwa w Polsce, tym razem za 2012 rok. Raport składa się z dwudziestu rozdziałów, liczy czterysta stron, na których zawarto różne informacje, w tym dane statystyczne, wykresy i tabele. Pomijając pierwszą rodzącą się wątpliwość - do kogo adresowany jest ten raport oraz w jakim celu został napisany, autor pragnie podzielić się niektórymi refleksjami, rodzącymi się po lekturze jego treści. Stąd nawiązanie do wieloznaczności pojęcia „bezpieczeństwo” i problemu z jego oceną oraz czynnikami mającymi wpływ na poczucie bezpieczeństwa. Po przybliżeniu niektórych danych statystycznych z raportu o zagrożeniach przestępczością oraz wykroczeniami, zostanie podjęta próba oceny efektywności podejmowanych działań przez niektóre służby policyjne. Jak się wydaje, takiego szerszego spojrzenia brakuje w raporcie, co utrudnia właściwą analizę opisanego w nim stanu. Misją policji jest służenie społeczeństwu. Ocena jej skuteczności i efektywności dokonuje się przede wszystkim w odbiorze społecznym, a wyraża się poczuciem bezpieczeństwa. Wydaje się, że jest to najbardziej obiektywna ocena realizacji jej działań. Wskaźniki statystyczne natomiast, postrzegane winny być, jako narzędzie służące poznaniu prawdy.

Jeżeli artykuł ten, przyczyni się chociażby w niewielkim stopniu do nieco głębszego spojrzenia na sygnalizowany w dalszej części problem, jego cel zostanie osiągnięty.

\section{BEZPIECZEŃSTWO I JEGO WIELOZNACZNOŚĆ}

„Bezpieczeństwo”, jako pojęcie ma wiele znaczeń i w różnym kontekście jest używane. Analizując treść opracowań nawiązujących do problematyki bezpieczeństwa, można pokusić się o stwierdzenie, że jest to abstrakcyjny termin określający złożony zespół pojęć (Swół, 2012: 42). Kiedy sięgniemy po słowniki, przeczytamy, że „,bezpieczeństwo” można zapewnić lub naruszyć, albo zagrażać czyjemuś bezpieczeństwu. Bezpieczeństwo ze względu na pożar (rzadziej od pożaru, bezpieczeństwo pod względem pożarowym). Wyraz „,bezpieczny” może być stopniowany, bezpieczniejszy albo bardziej bezpieczny. Ma także dwa znaczenia. W znaczeniu pierwszym ,niczym nie zagrażający”: bezpieczna droga, bezpieczna odległość. W znaczeniu drugim „niczym nie zagrożony”: był bezpieczny w tej kryjówce, bezpieczny, od kogo, czego: tu są bezpieczni od wrogów (Słownik poprawnej, 1980: 40). W słowniku frazeologicznym języka polskiego, ,bezpieczeństwo" to: bezpieczeństwo osobiste, publiczne (kogo), bezpieczeństwo życia i mienia, gwarancja bezpieczeństwa. Ale także: naruszać, utrzymywać, zapewnić bezpieczeństwo; zagrażać bezpieczeństwu; strzec bezpieczeństwa (np. granic); czuwać nad bezpieczeństwem (kogo lub czego) (Skorupka, 1985: 98). „Bezpieczny”, w znaczeniu: bezpieczna 
droga, odległość; być, poczuć się bezpiecznym; ukryć się w bezpiecznym miejscu; droga bezpieczna od rozbojów; od wszelkiej krzywdy bezpieczny (Skorupka, 1985: 98). W słowniku z początku XXI w., pod hasłem „bezpieczeństwo” wskazano:

1) stan psychiczny lub prawny, w którym jednostka ma poczucie pewności, oparcie w drugiej osobie lub sprawnie działającym systemie prawnym; przeciwieństwo zagrożenia: Poczucie bezpieczeństwa dziecka w rodzinie. Debata nad bezpieczeństwem publicznym. System bezpieczeństwa międzynarodowego;

2) instytucja powołana do egzekwowania norm prawnych z zakresu bezpieczeństwa publicznego; bezpieka: Aparat bezpieczeństwa. Także: kaftan bezpieczeństwa; pas bezpieczeństwa; stróż bezpieczeństwa; wentyl bezpieczeństwa; wyjście bezpieczeństwa.

Z kolei termin „bezpiecznie” oznaczał:

1) tak, aby dać poczucie bezpieczeństwa, chronić przed zagrożeniem: np. Bezpiecznie ukryć pieniądze;

2) tak, aby mieć poczucie bezpieczeństwa, nie być zagrożonym: np. Chcemy dobra bliskiego człowieka, coraz lepiej go rozumiemy, czujemy się przy nim bezpiecznie (Stownik wspótczesny, 2001: 50).

Nawiązanie do słowników w kontekście analizowanego pojęcia, pozwala mówić, iż w różnych kontekstach jest ono używane, a wieloznaczność pojęcia „bezpieczeństwo” jest bezdyskusyjna. Henryk Lisiak zauważa, że bezpieczeństwo to jedna z kardynalnych potrzeb ludzkich. Jego obecność lub brak ma istotny wpływ na treść oraz jakość wszelkich poczynań człowieka, rzutując jednocześnie na proces jego „stawania się”. Problematykę związaną z bezpieczeństwem widzi, jako bardzo rozległą problematykę, a zarazem żyzną krainę naukowej eksploracji. Bogata literatura przedmiotu, pozwala rozpatrywać bezpieczeństwo w różnych przestrzeniach i odniesieniach (Bezpieczeństwo, 2012: 7), a pojęcie „bezpieczeństwo” ma wiele definicji. Andrzej Urban w podręczniku akademickim podaje, że „w słowniku terminów w zakresie bezpieczeństwa narodowego zaproponowano kilkaset definicji związanych z bezpieczeństwem i obronnością" (Urban, 2011: 12-15). Bezpieczeństwo, chociaż rozmaicie definiowane i rozumiane jest zawsze umieszczane na czołowym miejscu wśród listy wartości pożądanych i chronionych tak przez jednostki, jak i podmioty zbiorowe. Kwestia uzyskania i utrzymania optymalnego $\mathrm{w}$ danych warunkach stanu bezpieczeństwa stanowi w związku z tym jeden z zasadniczych celów ludzkiego działania. Bezpieczeństwo absolutne i powszechne może mieć tylko charakter ideału wyobrażanego, pożądanego lub stanu postulowanego, lecz w praktyce, jak podpowiada doświadczenie, stanu bezpieczeństwa absolutnego, mimo starań i wysiłków nie osiagniemy. Wynika to ze złożoności mechanizmów społecznych i przyrodniczych, które powoduja, że mimo bogatych doświadczeń, poznania i opanowania wielu metod zwalczania zagrożeń godzących w bezpieczne bytowanie rodzaju ludzkiego, musimy uznać fakt, iż nieustannie towarzyszą nam one nie tylko, jako negatywny potencjał zgromadzony w otaczającym świecie, ale także, jako konkretne, mające różne formy zjawiska i zdarzenia. Mając tego świadomość, człowiek konsekwentnie od zarania dziejów, swoimi działaniami zmierza do oddalania, minimalizowania oraz przejmowania kontroli nad zagrożeniami (Fehler, Dziubek, 2010: 9). Przybliżając istotę bezpieczeństwa, Stanisław Koziej pisze, że najczęściej definiuje się go zarówno, jako stan (osiagnięte poczucie bezpieczeństwa danego podmio- 
tu), jak i proces (zapewnienia poczucie bezpieczeństwa podmiotu). Uważa, że podmiotem bezpieczeństwa mogą być wszystkie jednostki mające własne interesy i wyrażające ambicje realizacji tych interesów. Mogą to być pojedyncze osoby, różne grupy społeczne, narody, społeczności międzynarodowe i wreszcie cała ludzkość (Koziej, 2011: 20). W szerszym wymiarze bezpieczeństwo postrzega i opisuje Witold Pokruszyński. Prezentuje stanowisko, że w badaniach bezpieczeństwa, należy wyróżniać wyzwania i zagrożenia, bowiem tylko takie podejście może doprowadzić do obiektywnej oceny zjawiska bezpieczeństwa. Bezpieczeństwo odmiennie (niż Stanisław Koziej) rozpatruje w trzech znaczeniach. W pierwszym jest powszechnie określanie go, jako stanu spokoju, pewności, wolności od zagrożeń, a także strachu. W drugim znaczeniu, jako proces, w którym stan bezpieczeństwa i jego organizacja podlegają permanentnym, dynamicznym zmianom, stosownie do naturalnych oddziaływań i uwarunkowań. Innymi słowy, bezpieczeństwo oznacza ciagłą działalność (aktywność) człowieka, społeczności lokalnych, państw i organizacji międzynarodowych w tworzeniu (dążeniach do) pożądanego stanu bezpieczeństwa. W trzecim znaczeniu, to rozumienie go, jako naczelnej potrzeby i wartości człowieka oraz jego istnienia (Pokruszyński, 2011:10-11). Troska o bezpieczeństwo przejawia się w bardzo wielu działaniach człowieka. Dążąc do poznania zjawisk i mechanizmów otaczającego go świata, człowiek stara się przede wszystkim zapewnić sobie i swoim najbliższym bezpieczeństwo. Przez fakty, do których nastąpiło krótkie nawiązanie, problematyka bezpieczeństwa była i jest przedmiotem zainteresowania wielu dyscyplin naukowych. W opracowaniach naukowych bezpieczeństwo określane jest, jako stan pozytywny (Misiuk, 2011: 15; Serafin, Parszowski, 2011: 33; Urban, 2011: 15). Charakterystycznymi elementami są: poczucie pewności i braku zagrożenia. Brak zagrożenia jest zjawiskiem obiektywnym, dającym się w wielu sytuacjach zdiagnozować. Warunkiem jest jednak, posiadanie odpowiedniej wiedzy i narzędzi umożliwiających dokonanie oceny otaczającej nas rzeczywistości, pod kątem stwierdzenia lub ujawnienia czynników zagrażających chronionym dobrom lub wartościom. Drugi element wchodzący w tak rozumiany stan - poczucie pewności, inaczej wolność od zagrożeń, ma charakter subiektywny (Pieprzny, 2012: 9). W kontekście dalszych rozważań, już obecnie należy powiedzieć, że poczucie bezpieczeństwa człowieka jest czymś, co nie tylko ulega zmianie w zależności od samopoczucia człowieka w danym momencie i okolicznościach, ale zależy od jego cech psychofizycznych i czynników zewnętrznych, czyli otoczenia. Przykładem na to stwierdzenie może być okoliczność, że inaczej na zagrożenie zareaguje policjantka, a inaczej policjant w podobnych okolicznościach, np. podejmując interwencję w ochronie naruszonego porządku prawnego (Swół, 2012: 38-49). Tak samo możemy powiedzieć o zróżnicowanej reakcji kobiety i mężczyzny, czy też osób o tej samej płci, lecz różnym doświadczeniu życiowym (zawodowym) czy też warunkach fizycznych, umiejętnościach, porze dnia bądź wieku. Ten przykład prowadzi nas do związku bezpieczeństwa z nauką psychologii, a także do następującej konstatacji. Przy próbie opisywania bezpieczeństwa przy wykorzystaniu wskaźników statystycznych, musimy uwzględniać pojęcia lęku i strachu (Kokoszka, 2013) ${ }^{1}$. Należy pamiętać przy tym, że w literatu-

${ }^{1}$ Andrzej Kokoszka tak definiuje te pojęcia. „Lęk to naturalne uczucie obawy przed zagrożeniem, które pozwala je zauważyć i podjąć odpowiednie działania. Jeżeli przyczyna niebezpieczeń- 
rze kryminologicznej istnieje problem $\mathrm{z}$ definiowaniem tych pojęć. $\mathrm{W}$ badaniach empirycznych występują kłopoty z ich operacjonalizacją (Stownik, 2013) ${ }^{2}$. Strach przed przestępczością, traktuje się, jako konglomerat różnych myśli i odczuć. Konstrukcja ta składa się z trzech składników: emocjonalnego, racjonalnego oraz behawioralnego (Błachut, Gaberle, Krajewski, 2007: 450-452). Wskaźnikiem składnika emocjonalnego (afektywnego) będzie subiektywne poczucie bezpieczeństwa lub niebezpieczeństwa. Subiektywne poczucie bezpieczeństwa mierzone jest poprzez zadawanie odpowiednich pytań (,Jak bezpiecznie czujesz się w swoim mieszkaniu w nocy, kiedy jesteś sam?”, „Czy jest miejsce w twojej okolicy, gdzie boisz się spacerować sam podczas dnia?"). O strach przed wiktymizacją dowiadujemy się poprzez stawianie pytania, np.: „Czy odczuwasz strach przed staniem się ofiarą przestępstwa (włamania, napadu, kradzieży)?” Wskaźnikiem składnika racjonalnego (kognitywnego) jest ocena rozwoju przestępczości oraz ryzyko związane ze staniem się ofiarą (prawdopodobieństwo wiktymizacji). Ocenę rozwoju bada się także poprzez zadawanie respondentom odpowiednich pytań („Czy masz odczucie, że w ciagu ostatnich dwóch lat problem przestępczości w twojej okolicy zwiększył się, zmniejszył lub utrzymuje się na tym samym poziomie?"). Oceny ryzyka wiktymizacji nie można utożsamiać ze strachem przed stania się ofiarą. „Bowiem jest możliwe, że oceniając prawdopodobieństwo wiktymizacji (np. przestępstwem rozboju) jako małe, można mimo tego odczuwać strach przed wyktymizacją tym przestępstwem. Możliwe jest również, iż ktoś, np. młody mężczyzna nieunikający walki, mimo dużego prawdopodobieństwa wiktymizacji, w ogóle albo w bardzo niewielkim stopniu odczuwa strach przed wyktymizacją (przestępstwem pobicia)" (Błachut, Gaberle, Krajewski, 2007: 451-452). Jak zatem należałoby rozumieć pojęcie bezpieczeństwa, aby podjąć próbę statystycznego opisu bezpieczeństwa w Polsce? Dla dalszych rozważań, autor proponuje posłużeniem się pojęciem „,bezpieczeństwa", jako takiego stanu, w którym prawdopodobieństwo wystapienia szkody dla osób lub mienia jest zminimalizowane na tyle, że nie odczuwamy zagrożenia, albo występuje ono w takim stopniu, że w ramach procesu bieżącego analizowania tego stanu, oceniamy, że znajduje się na dopuszczalnym, akceptowanym przez jednostkę poziomie lub poniżej tego stanu (Szymik, 2013: 648). Propozycja takiego właśnie rozumienia tego pojęcia, wynika z następującej przyczyny. Od 2008 roku w raportach o stanie bezpieczeństwa w Polsce, ministerstwo spraw wewnętrznych, wykorzystuje dane obrazujące stan zagrożenia przestępczością oraz wykroczeniami, do opisu oraz oceny stanu bezpieczeństwa. Jeżeli za Stanisławem Pieprznym i innymi autorami (Jasiński, 2013) przyjmiemy, że bezpieczeństwo, to pozytywny stan, wówczas operowanie statystykami o ujawnionych przestępstwach i wykroczeniach, świadczy o stanie negatywnym, a zatem o zagrożeniach. Bez wątpienia wielowątkowa analiza, dokonywana przy wykorzystaniu danych statystycznych w raportach za lata 2008-2012, jawi się, jako prosty sposób oceny złożonej problematyki bezpieczeństwa. Jednakże dane statystyczne nie

stwa jest rozpoznawana, używa się pojęcia strachu, a jeśli jest trudna do sprecyzowania - pojęcia lęku. Stany patologiczne charakteryzuje nasilenie nieadekwatne do przyczyny, które jest źródłem cierpienia i utrudnia funkcjonowanie".

${ }^{2}$ Operacjonalizacja w metodzie naukowej badań: doprowadzanie wskaźników i zmiennych do postaci dającej się precyzyjnie wyrazić. 
obrazują bezpieczeństwa, a stan zagrożenia różnego rodzaju negatywnymi (niepożądanymi) zdarzeniami lub zjawiskami (Swół, 2012: 26-34).

\section{PROBLEM OCENY STANU BEZPIECZEŃSTWA}

Bezpieczeństwo z uwagi na jego wieloznaczność, to pojęcie względne. Abstrahując od wskaźników statystycznych przestępczości, jako punktu odniesienia, przy próbach oceny stanu czy poziomu poczucia bezpieczeństwa, można posługiwać się innymi wskaźnikami. Zastanówmy się, czy przez fakt, iż ustawa o środkach przymusu bezpośredniego i broni palnej (Ustawa, 2013) ${ }^{3}$, która uprawnia w sumie 25 podmiotów do użycia lub wykorzystania środków przymusu bezpośredniego, takiego stanu nie podpowiada interpretować, jako stanu zagrażającemu naszemu bezpieczeństwu? Należy mieć przy tym na uwadze, że w obszarze ochrony bezpieczeństwa i porządku publicznego funkcjonują: formacje umundurowane i uzbrojone; straże umundurowane i uzbrojone oraz straże umundurowane - nieuzbrojone; inspekcje i służby nadzorcze; finansowe i niefinansowe organy dochodzenia w sprawach o przestępstwa i wykroczenia; jednostki gospodarcze ochrony osób i mienia oraz organy w sytuacjach kryzysowych i klęsk żywiołowych (Sławik, 2011). Wieloznaczność pojęcia „bezpieczeństwo”, nie ułatwia oceny działań wyspecjalizowanych organów państwowych podległych ministrowi spraw wewnętrznych (Swół, 2012: 43). W roku 2011 policja zatrzymała na gorącym uczynku popełnienia przestępstwa lub bezpośrednio po jego popełnieniu 316812 osób. Liczba ta wynika z podsumowania meldunków dziennych policji. Osoby te, stanowią $59,9 \%$ osób podejrzanych, które wykazują policyjne statystyki za ten sam rok. Wynika z tego bardzo wysoka skuteczność, przede wszystkim służb prewencyjnych. Wyprowadzony wniosek z takiego porównania może być następujący - możemy czuć się bezpieczni w miejscach publicznych. Można jeszcze inaczej analizować problem stanu bezpieczeństwa. Zatrudnienie w Policji (policjanci + Korpus Służby Cywilnej) na dzień 1 stycznia 2013 roku, było mniejsze od stanu etatowego. Na możliwy etatowy stan 114 448,5 etatów, zatrudnionych było 107999 osób. Mamy prawo przyjmować, że kierownictwo formacji odpowiedzialnej za stan porządku i bezpieczeństwa publicznego, ocenia stan naszego bezpieczeństwa na takim poziomie, że nie zachodzi potrzeba zatrudnienia 6094 funkcjonariuszy oraz 355 pracowników korpusu służby cywilnej. Uwzględniając tylko wakaty policyjne, przez 220 dni w roku, w służbie mamy 3047 patroli mniej. A skoro jest bezpiecznie, można postawić pytanie. Dlaczego pozapaństwowe podmioty ochrony osób i mienia zatrudniają około 250 tys. pracowników (Pieprzny, 2011: 78), czyli dwa razy tyle, co Policja?

W dalszych rozważaniach, nasza uwaga zostanie skupiona, na informacjach zawartych w Raporcie o stanie bezpieczeństwa w Polsce w 2012 roku (Raport, 2012). W ocenie

\footnotetext{
3 Ustawa treścią art. 2. nadaje uprawnienia do użycia lub wykorzystania takich środków funkcjonariuszom, strażnikom, żołnierzom, pracownikom ochrony, inspektorom Inspekcji Transportu Drogowego, członkom służby porządkowej, pracownikom zakładów poprawczych, schronisk dla nieletnich lub młodzieżowych ośrodków wychowawczych.
} 
jego autorów, „ostateczny kształt Raportu ... zasadniczo podsumowuje stan bezpieczeństwa w Polsce w roku 2012 i latach poprzednich" (Raport, 2013: 5). Czy możliwe jest przedstawianie stanu bezpieczeństwa, przy wykorzystaniu statystyki publicznej prowadzonej w Polsce na podstawie ustawy (Ustawa, 1995)? Pytanie to jest o tyle uzasadnione, że w tym obszernym dokumencie, bardzo bogatym źródle informacji, operuje się danymi, które obrazują efekty będące wynikiem przeciwdziałania zagrożeniom, lub eliminowaniu ich skutków. A więc w raporcie zawarto efekty czy wyniki pracy. Raport nie zawiera oceny bezpieczeństwa w analizowanej problematyce, w sposób przekonywujący. Jego końcową częścią są rekomendacje (Raport, 2013: 396-398). Próbę odpowiedzi na zasygnalizowany problem wynikający z pytania, należy poprzedzić informacją, że ustawa o statystyce publicznej z 1995 roku, określa zasady i tworzy podstawy rzetelnego, obiektywnego, profesjonalnego i niezależnego prowadzenia badań statystycznych, w których wyniki mają charakter oficjalnych badań statystycznych, oraz ustala organizację i tryb prowadzenia tych badań i zakres związanych z tym obowiązków (Choromańska, 2008: 59). Dane statystyczne gromadzone poprzez odpowiednie procedury obowiązujące policję, prokuratury, sądy (i nie tylko), zbierane są w sposób uporządkowany. Przetworzone następnie w systemach informatycznych, obrazują nam skalę jakiegoś zjawiska. Gromadząc i przetwarzając dane poznajemy przykładowo: liczbę przestępstw stwierdzonych, liczbę postępowań wszczętych, liczbę podejrzanych, oskarżonych, skazanych, uniewinnionych, liczbę grzywien nałożonych w postępowaniu mandatowym itp. Takim celom już od bardzo dawna służą statystyki kryminalne przestępczości. Względy praktyczne zadecydowały o rozwoju takiej statystyki, począwszy od XIX w. Na potrzeby sądu pierwsze statystyczne dane zaczęły ukazywać się we Francji. W ślad za nią poszły inne kraje (Swół, 1999: 31). W literaturze kryminologicznej słusznie podnosi się, iż statystyka przestępczości jest niezastąpionym, chociaż dalekim od doskonałości, środkiem poznania pewnych faktów (Horoszowski, 1965: 44). O zbiorach danych składających się na statystyki kryminalne będzie mowa szerzej nieco później, ale odpowiedź na postawione pytanie, nakazuje podjąć próbę odpowiedzi już teraz. Dla przypomnienia, chodzi o pytanie: „Czy możliwe jest przedstawianie stanu bezpieczeństwa, przy wykorzystaniu statystyki publicznej prowadzonej w Polsce?” Odpowiedź jednak nie może być jednoznaczna. Zbiory policyjnych danych statystycznych to narzędzie poznania oraz informacja, co zrobiono oraz jak zrobiono. Poprzez interpretację danych statystycznych, wyprowadza się wnioski, co należy robić w przyszłości w zakresie walki z przestępczością. Bogactwo informacji zawartych w statystykach policyjnych pozwala przyjać, że statystyka służy „do określenia stanu zagrożenia, geografii przestępstw, budowania strategii aktywnego przeciwdziałania, podejmowania działań prewencyjnych i operacyjnych, jak też wyrażenia skali obciążenia pracą komórek i jednostek oraz efektywności i skuteczności działania. Służy oczywiście organom władzy, jako informacja o stanie przestępczości i zagrożeń zarówno w skali kraju czy województwa, jak też informacja o skuteczności realizacji ogólnopolskich i regionalnych programów poprawy bezpieczeństwa. Statystyka przestępczości jest źródłem wiedzy i materiałem badawczym dla instytucji i placówek prowadzących badania nad przestępczością. Jest prezentowana w rocznikach statystycznych GUS, służy studentom piszącym prace dyplomowe, doktorantom, pracownikom dydaktyczno-nau- 
kowym różnych uczelni. Jest wreszcie częścią statystyk międzynarodowych, oenzetowskich i interpolowskich" (Borzęcki, 2000).

W świetle tego, co do tej pory zostało powiedziane, na uwidaczniający się problem z oceną stanu bezpieczeństwa, można powiedzieć w sposób następujący. Policyjna statystyka przestępczości, ułatwia formułowanie ocen w zakresie bezpieczeństwa. Nie pozwala jednak przedstawiać bezpieczeństwa liczbowymi wskaźnikami. Dlatego podejmując próby oceny stanu bezpieczeństwa, należy uwzględniać obywatelskie poczucie bezpieczeństwa oraz wyniki badań związanych z problematyką przestępczości nieujawnionej oraz statystyki przestępczości. Poczucie bezpieczeństwa ma charakter emocjonalny. Nie można go zobiektywizować w sensie dosłownym, ale poprzez korzystne statystyczne wskaźniki, kolorowe wykresy i odpowiednią narrację można kształtować pozytywny jego odbiór.

\section{POCZUCIE BEZPIECZEŃSTWA}

Wszelkie statystyki niezbędne do określenia częstotliwości występowania określonych zdarzeń (w naszej sytuacji przestępstw), to pewna specyficzna ilustracji historii. Statystyka wykazuje tylko to, co już się zdarzyło. Statystyka nie mówi nic o tym, co będzie. W tym wypadku posługujemy się prognozami (Wolanin, 2005: 27-28). Poczucie bezpieczeństwa to subiektywne odczuwanie różnych stanów. Relacje zachodzące między rzeczywistością a psychiką przekładają się na bezpieczeństwo i prowadzą do powstania czterech modelowych sytuacji: stanu braku bezpieczeństwa; stanu obsesji; stanu fałszywego bezpieczeństwa; stanu bezpieczeństwa (Brzeziński, 2009: 26). Ocena czy też odczuwanie tych stanów jest subiektywne w odbiorze. Jak trafnie pisze Ewa M. Marciniak, „poczucie, czyli subiektywne odczuwanie różnych stanów, dotyczy nie tylko bezpieczeństwa, ale również np. tożsamości (poczucia własnego istnienia), szczęścia, zadowolenia z życia. Pomiaru »poczuć« dokonuje się przez różnego rodzaju testy psychologiczne. $Z$ badań tych jednak można dowiedzieć się tylko tego, co osoby badane są skłonne ujawnić. Zatem o tym, czy ludzie doświadczają poczucia bezpieczeństwa lub zadowolenia z życia wiemy jedynie z ich relacji (np. określona osoba może mieć poczucie bezpieczeństwa i zarazem zaprzeczać, że czuje się bezpiecznie). Tę samą sytuację różne osoby mogą postrzegać, jako bezpieczną bądź niebezpieczną" (Marciniak, 2009: 58). W raporcie MSW z sierpnia 2013 r., przedstawione zostały wyniki badań w zakresie poczucia bezpieczeństwa Polaków (Raport, 2013: 14-24). Przeprowadzone zostały przez specjalistyczne pracownie, stąd od razu można przejść do wyników tych badań.

Badania prowadzone od ponad 10 lat dowodzą, że poczucie bezpieczeństwa Polaków jest wysokie, podobnie jak wskaźniki społecznych ocen pracy Policji, która jest służbą wykonującą najwięcej zadań związanych z zapewnieniem bezpieczeństwa w kraju (Raport, 2013: 14). Na pytanie: „Czy Polska jest krajem, w którym żyje się bezpiecznie? Według badań Centrum Badania Opinii Społecznej z kwietnia 2012 roku, 66\% Polaków uznawało swój kraj za bezpieczny. W kwietniu 2011 r. tak uważało 75\% Polaków. Jednocześnie 31\% Polaków w 2012 r. uważało, że nie. Oznacza to wzrost o 9\% w stosunku do badań przeprowadzonych rok wcześniej. 
„Czy Polska jest krajem, w którym żyje się bezpiecznie?” - wyniki badań w latach 2007-2012

\begin{tabular}{||c|c|c|c|c|c|c||}
\hline Rok & $\mathbf{2 0 0 7}$ & $\mathbf{2 0 0 8}$ & $\mathbf{2 0 0 9}$ & $\mathbf{2 0 1 0}$ & $\mathbf{2 0 1 1}$ & $\mathbf{2 0 1 2}$ \\
\hline Tak \% & 53 & 68 & 69 & 70 & 75 & 66 \\
\hline Nie \% & 43 & 30 & 29 & 26 & 22 & 31 \\
\hline
\end{tabular}

CBOS na próbie $\mathrm{N}=1018$.

Źródło: Opracowania własne, na podstawie: Raport o stanie bezpieczeństwa w Polsce w 2012 roku, Warszawa 2013, s. 15.

Kiedy taką samą liczbę osób ( $\mathrm{N}=1018)$, zapytano o poczucie bezpieczeństwa w najbliższej okolicy ich miejsca zamieszkania (w dzielnicy, na osiedlu, na wsi itd.), okazało się, że $89 \%$ Polaków swoje otoczenie uznało za bezpieczne i spokojne.

Tabela 2

„Czy miejsce, w którym Pan(i) mieszka, można nazwać bezpiecznym i spokojnym?" - wyniki badań w latach 2007-2012

\begin{tabular}{||c|c|c|c|c|c|c||}
\hline Rok & $\mathbf{2 0 0 7}$ & $\mathbf{2 0 0 8}$ & $\mathbf{2 0 0 9}$ & $\mathbf{2 0 1 0}$ & $\mathbf{2 0 1 1}$ & $\mathbf{2 0 1 2}$ \\
\hline Tak \% & 81 & 87 & 88 & 86 & 88 & 89 \\
\hline Nie \% & 18 & 12 & 12 & 13 & 11 & 9 \\
\hline \hline
\end{tabular}

CBOS na próbie $\mathrm{N}=1018$.

Źródło: opracowania własne na podstawie: Raport o stanie bezpieczeństwa w Polsce w 2012 roku, Warszawa 2013, s. 15.

Wyniki badań pozwalają przyjąć także, że 59\% dorosłych Polaków nie obawiała się, iż może stać się ofiarą przestępstwa. Od poprzedniej edycji badania (kwiecień 2011 roku) odsetek badanych Polaków, którzy nie obawiają się, że mogą stać się ofiarami przestępstw, zmniejszył się o $2 \%$. Jednocześnie 39\% respondentów stwierdziło, że obawiają się, że mogą stać się ofiarami przestępstw. W kwietniu 2011 roku odsetek respondentów, którzy obawiają się, że mogą stać się ofiarami przestępstw, wzrósł o $2 \%$. Inaczej mówiąc, wzrosło poczucie zagrożenia.

„Czy obawia się Pan(i) tego, że może się Pan(i) stać ofiarą przestępstwa?" - wyniki badań w latach 2007-2012

\begin{tabular}{||c|c|c|c|c|c|c||}
\hline Rok & $\mathbf{2 0 0 7}$ & $\mathbf{2 0 0 8}$ & $\mathbf{2 0 0 9}$ & $\mathbf{2 0 1 0}$ & $\mathbf{2 0 1 1}$ & $\mathbf{2 0 1 2}$ \\
\hline Tak \% & 54 & 59 & 58 & 53 & 61 & 59 \\
\hline Nie \% & 44 & 40 & 41 & 46 & 37 & 39 \\
\hline
\end{tabular}

CBOS na próbie $\mathrm{N}=1018$.

Źródło: Opracowania własne na podstawie: Raport o stanie bezpieczeństwa w Polsce w 2012 roku, Warszawa 2013, s. 16.

Przy tej okazji warto odnieść się do poczucia bezpieczeństwa Polaków w ramach innych badań. Polskie Badanie Przestępczości (PBP) to badanie opinii społecznej zreali- 
zowane od 2007 r. przez KGP. Badanie to dotyczy przede wszystkim oceny pracy policjantów, ale także można znaleźć pytanie dot. poczucia bezpieczeństwa. Były one realizowane na dużej próbie 17 tys. Polaków powyżej piętnastego roku życia - po 1000 respondentów (losowa próba reprezentatywna) w każdej komendzie wojewódzkiej oraz Komendzie Stołecznej Policji.

Polskie Badanie Przestępczości, ze względu na sposób wykorzystywania jego wyników, jest realizowane zawsze w styczniu danego roku. Badania CBOS, których wyniki zostały wykazane w tabelach (nr 1, 2 i 3) wcześniej, prowadzone były w miesiącach: marcu lub kwietniu.

„Czy czuje się Pan(i) bezpiecznie, spacerując w swojej okolicy po zmroku?" - wyniki badań w latach 2007-2013

\begin{tabular}{||c|c|c|c|c|c|c|}
\hline \hline Rok & $\mathbf{2 0 0 7}$ & $\mathbf{2 0 0 8}$ & $\mathbf{2 0 0 9}$ & $\mathbf{2 0 1 1}$ & $\mathbf{2 0 1 2}$ & $\mathbf{2 0 1 3}$ \\
\hline Tak \% & 70,1 & 75,5 & 77,2 & 79,3 & 80,2 & 75,5 \\
\hline Nie \% & 26,2 & 21,5 & 19,7 & 17,1 & 16,7 & 21,0 \\
\hline
\end{tabular}

KGP, PBP na próbie $\mathrm{N}=17.000$.

Źródlo: opracowanie własne na podstawie: Raport o stanie bezpieczeństwa w Polsce w 2012 roku, Warszawa 2013, s. 19.

Widać z wyników badań zamieszczonych $\mathrm{w}$ tabeli $2 \mathrm{i}$ tabeli 4, że respondenci okolice, w której mieszkali, oceniali jako bezpieczną i spokojną w wyższym stopniu niż w odniesieniu do całego kraju. Można jeszcze dodać, że badania prowadzone w styczniu 2012 roku w ramach PBP, dostarczyły interesujących danych. Respondentom zadano pytanie: „Na czym przede wszystkim opera Pan(i) swoją ocenę pracy Policji?” Z badań wynika, że w 44,8\% - na własnych obserwacjach pracy Policji. Na własnych doświadczeniach w kontaktach z policją - $20 \%$, a na informacjach z prasy, radia, telewizji, Internetu $16,2 \%$. Opinie członków rodziny, sąsiadów, znajomych - to $15,7 \%$. Wcześniej o to samo nie pytano respondentów.

Już dawno zostało zauważone, że chociaż statystyka przestępczości często nie pokrywała się ze społecznymi odczuciami, nie szkodziło to wizerunkowi Policji. Mało optymistyczne wskaźniki wykrywalności przestępstw w latach 1990-1991, wzrost dynamiki przestępczości, nie przeszkadzały pozytywnemu postrzeganiu policjantów. Policja w sondażach plasowała się na drugim miejscu za Kościołem katolickim. Ocena działalności Policji w marcu 2013 r. wygląda mniej korzystnie. Spośród 28 ocenianych instytucji, Policja zajęła 8-9 miejsce. Natomiast w porównaniu do badań z września 2012 r., pozytywne oceny spadły aż o 11\% (Raport, 2013: 18). Pomimo zanotowanego spadku (68 do 57\%), autorzy raportu uważają, że ocena Policji jest w dalszym ciągu wysoka. Analizując treść raportów MSW, można zaryzykować twierdzenie, że poprzez optymistyczne wskaźniki statystyczne, ich autorzy przysłaniają niekiedy mało optymistyczną rzeczywistość. To stwierdzenie będzie miało uzasadnienie już niebawem. W tym miejscu podnieść należy, iż w najmniejszym stopniu nie zdezaktualizowały się twierdzenia, że „Działalność organów ścigania, a przede wszystkim ich skuteczność, społeczeństwo ocenia przez pryzmat własnego bezpieczeństwa i stosunku policjantów 
do osoby pokrzywdzonej przestępstwem” (Swół, 1998: 27), a także takie, że „decydujące są odczucia dotyczące osobistej sytuacji oraz najbliższego otoczenia" (Czapska, 1999: 153). Co drugi Polak za najważniejsze uważa szybkie przybycie policjantów po wezwaniu na miejsce zdarzenia, jest to dla niego najistotniejszą kwestią wiążącą się z pracą policji (Raport, 2013: 24) ${ }^{4}$. Jeżeli po przybyciu nastąpi jeszcze profesjonalna obsługa miejsca zdarzenia, pokrzywdzony czy świadkowie spotkają się z życzliwością policjantów, usłyszą zapewnienie, że sprawca zostanie ustalony i ukarany itp., to z pewnością taka postawa, budować będzie zaufanie oraz poczucie bezpieczeństwa. To wynika $\mathrm{z}$ doświadczeń praktyki. Kiedyś w środowisku dzielnicowych z dobrym skutkiem wykorzystywano zasadę, że „klient może być niezałatwionym, byle wyszedł zadowolony".

\section{PRZESTĘPSTWA STWIERDZONE I ICH GEOGRAFIA}

Przestępstwa stwierdzone oraz zagrożenia związane z wykroczeniami bardzo szeroko zostały zaprezentowane w raporcie. Stan zagrożenia w 2012 r., został przedstawiony, w porównaniu do lat wcześniejszych. Próbę krótkiego nawiązania do skali zagrożenia przestępstwami stwierdzonymi, wypada poprzedzić informacją że współcześnie w polskich realiach podstawowym źródłem informacji o przestępczości ujawnionej są statystyki kryminalne. Mowa o zbiorach, czy zespołach danych zbieranych, gromadzonych, opracowywanych i publikowanych przez organy ścigania i wymiaru sprawiedliwości.

Aktualnie istnieją cztery rodzaje statystyk kryminalnych: policyjna, prokuratorska, sądowa i penitencjarna. Statystyka prowadzono przez organy ścigania w ostatnich kilkudziesięciu latach ulegała w naszym kraju istotnym zmianom (Błachut, Gaberle, Krajewski, 2007: 193). Zmiany te niekoniecznie sprzyjały poznaniu skali np. przestępczości stwierdzonej w sensie ogólnym, czy też w poszczególnych kategoriach przestępstw. Już K. Sławik zwracał uwagę, że statystyki budzą kontrowersje, bo „W praktyce zdarzały się przypadki »dopasowywania« statystyki do różnych okazji” (Sławik, 1978: 589). Podnosił przy tym wątpliwość, czy statystka stanowi „obiektywny miernik oceny stanu bezpieczeństwa i porządku publicznego" (ibidem: 589). Wątpliwość taką należy podnieść także do aktualnych zasad przetwarzania informacji w ramach Krajowego Systemu Informacyjnego Policji (KSIP) (Gruza, Goc, Moszczyński, 2008: 578-580; Hołyst, 2010: 1026). . To właśnie według nowych zasad, od kwietnia

4 Tak wynika z badań ze stycznia 2013 r. Rok wcześniej, tak uważało 45,2\% respondentów.

5 KSIP w 2003 r. zastapił Zintegrowany System Informacji Policyjnej (ZSIP), który funkcjonował od połowy lat 90 . ub. wieku. Aktualnie KSIP jest podstawowym systemem informatycznym Policji, który pozwala gromadzić, przetwarzać i uzyskiwać informacje kryminalne. Prowadzony jest w KGP dla całego terytorium kraju oraz złożony ze zbiorów danych: zbioru Osoba; zbioru Fakt; zbioru Rzecz; zbioru Przedmiot. W KSIP przetwarza się informacje, w tym dane osobowe, o których mowa w art. 20 ust. 1, 2a, 2aa, 2b, i art. 15 ustawy z 6 kwietnia o Policji (Dz. U. 2011, Nr 297, poz. 12687 ze zm.). W KSIP przetwarza się również informacje stanowiące dane statystyczne o przestępstwach, zamachach samobójczych i wypadkach tonięcia w zakresie, trybie i formie określonej w przepisach wydanych na podstawie art. 18 ustawy z 29 czerwca 1995 r. o statystyce publicznej (Dz. U. 2012, poz. 591 ze zm.). Szczegółowe kwestie reguluje decyzja nr 125 Komendanta Głównego 
2013 roku gromadzi się dane przydatne w pracy policji, w tym dane statystyczne o przestępstwach. Stąd krótkie nawiązanie, do KSIP bez wchodzenia w szczegóły. Przy okazji jedna uwaga praktyczna. Porównywanie danych z 2012 r. oraz z 2013 r. może niekiedy tworzyć fałszywy obraz zjawiska, które chcemy poznać. Nowe zasady nie stoją na przeszkodzie temu, aby dane statystyczne z roku 2012 porównywać z latami wcześniejszymi.

Przestępczość stwierdzoną wykazuje się po zakończeniu dochodzenia lub śledztwa w zależności od sposobu jego zakończenia ${ }^{6}$. Skala przestępczości stwierdzonej świadczy o zagrożeniach, natomiast poprzez porównanie np. przy uwzględnieniu województw, kształtujemy swoją ocenę, gdzie jest bardziej bezpiecznie, albo odwrotnie. Uprzedzając nieco fakty, na podstawie wykresu nr 1 można mówić, że województwo podkarpackie, zaliczyć należy do bezpiecznych. Z kolei województwa: dolnośląskie, lubuskie i śląskie to najbardziej zagrożone biorąc pod uwage przestępczość stwierdzoną. W odniesieniu do całego kraju, takie porównanie byłoby możliwe, gdybyśmy znali rzeczywiste rozmiary przestępczości. Skali przestępczości rzeczywistej niestety nie znamy (Hołyst, 1979: 29) ${ }^{7}$. Przy opisie zagrożenia i prezentacji danych zawartych w statystyce policyjnej, używa się liczb bezwzględnych, odsetek, współczynników przestępczości, wykorzystuje się także wskaźniki wykrywalności czy dynamiki (Błachut, Gaberle, Krajewski, 2007: 195). Wskaźnik przestępczości to liczba przestępstw stwierdzonych, która przypada w przeliczeniu na 100 tys. mieszkańców. Przelicznik taki umożliwia porównanie stopnia zakłócenia porządku prawnego $\mathrm{w}$ danym okresie na danym terytorium. Po wyliczeniu średniej krajowej (wskaźnik dla Polski 2906), wyliczany może być wskaźnik dla danego województwa bądź powiatu.

Po tym krótkim wprowadzeniu, można przybliżyć niektóre dane statystyczne związane z zagrożeniami oraz efektami pracy policjantów. Według policyjnej statystyki, w roku 2012 policja zakończyła 1026703 postępowania przygotowawcze. Aby nie wchodzić zbyt głęboko w sposób ich zakończenia, należy napisać, że w śród tych postępowań były takie, które zakończyły się wnioskiem o wniesienie aktu oskarżenia, umorzeniem postępowania wobec niewykrycia sprawcy (sprawców) przestępstwa lub innych przyczyn, bądź z braku znamion czynu zabronionego. Z powodu niewykrycia sprawcy umorzono 374847 postępowań (36,5\% ogółu zakończonych). Z braku znamion czynu zabronionego 154289 postępowań (15\%) oraz 23507 po wykonaniu czynności w trybie art. 308 lub 17 § 2 k.p.k., to jest bez wszczynania postępowania $(2,29 \%$

Policji z dnia 5 kwietnia 2013 r. w sprawie funkcjonowania Krajowego Systemu Informacyjnego Policji (Dz. Urz. KGP z 6.04.2013 r., poz. 28).

6 W uproszczeniu można powiedzieć, że za przestępstwo stwierdzone (wykryte lub niewykryte) uznaje się takie zdarzenie, które ma charakter przestępny (wypełnia znamiona czynu zabronionego) i według oceny dokonanej przez prowadzącego postępowanie, potwierdza to przeprowadzone postępowanie. Natomiast za przestępstwo wykryte, uznaje się takie przestępstwo stwierdzone, którego popełnienie zarzucono przynajmniej jednemu podejrzanemu oraz przyjęto w zakończonym postępowaniu, że osoba ta popełniła zarzucany jej czyn lub czyny.

7 Przestępczość rzeczywista, to ogół czynów przestępnych, jakie popełnione zostały w danym czasie na określonym terenie. Zarówno wielkość, jak i struktura tego zbioru nie jest znana. Próby oszacowania rozmiarów przestępczości rzeczywistej prezentowane są w literaturze kryminologicznej w ramach problematyki tzw. ciemnej liczby. 
Wykres 1. Zagrożenie przestępczością w roku 2012 w przeliczeniu na 100 tys. mieszkańców z podziałem na województwa

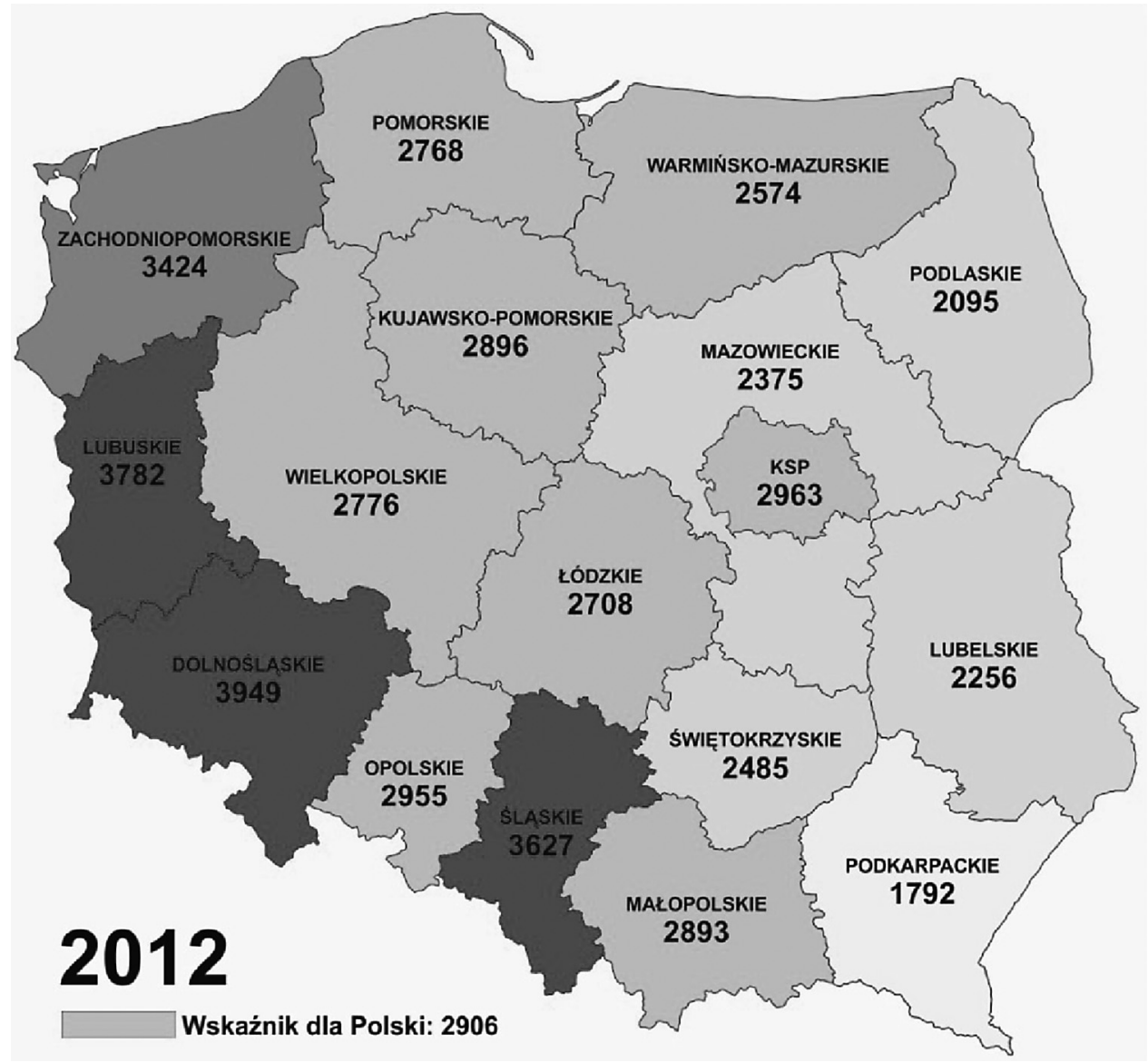

Źródlo: Raport o stanie bezpieczeństwa w Polsce w 2012 roku (2013), Warszawa, s. 10.

ogółu zakończonych). W postępowaniach tych nie stwierdzono popełnienie przestępstwa. W postępowaniach, w których wykryto lub nie wykryto sprawcy przestępstwa, stwierdzono 1119803 przestępstwa. Wprawdzie statystyki nie pokazują ile przestępstw zostało wykrytych, ale znając wskaźnik wykrywalności za 2012 rok (wynosi on 67,8\%) łatwo obliczyć, że wykrytych zostało 759226 przestępstw (1 $119803=100 \%$; $67,8 \%=x)$. Przestępstwa te popełniło 500539 podejrzanych. Sprawców pozostałych przestępstw stwierdzonych, a jest ich 360 557, nie wykryto ${ }^{8}$. Najczęściej popełniane przestępstwa to: kryminalne (781 340 stwierdzonych); przestępstwa drogowe

8 Wynika to z wyliczenia: (Ogólna liczba przestępstw stwierdzonych) 1119803 - (przestępstwa w których ustalono sprawcę) 759 226-360 557 przestępstw, gdzie nie wykryto sprawcy. Pomińmy przy tym uwidaczniającą się niezgodność, biorąc pod uwagę liczbę postępowań umorzonych z powodu niewykrycia sprawcy przestępstwa (umorzono 374847 postępowań), co wynika z danych statystycznych KGP. 
(155 906) oraz gospodarcze (141 483). Wskaźnik zagrożenia przestępstwami kryminalnymi obrazuje wykres 2 .

Wykres 2. Zagrożenie przestępstwami kryminalnymi w 2012 roku w przeliczeniu na 100 tys. mieszkańców z podziałem na województwa

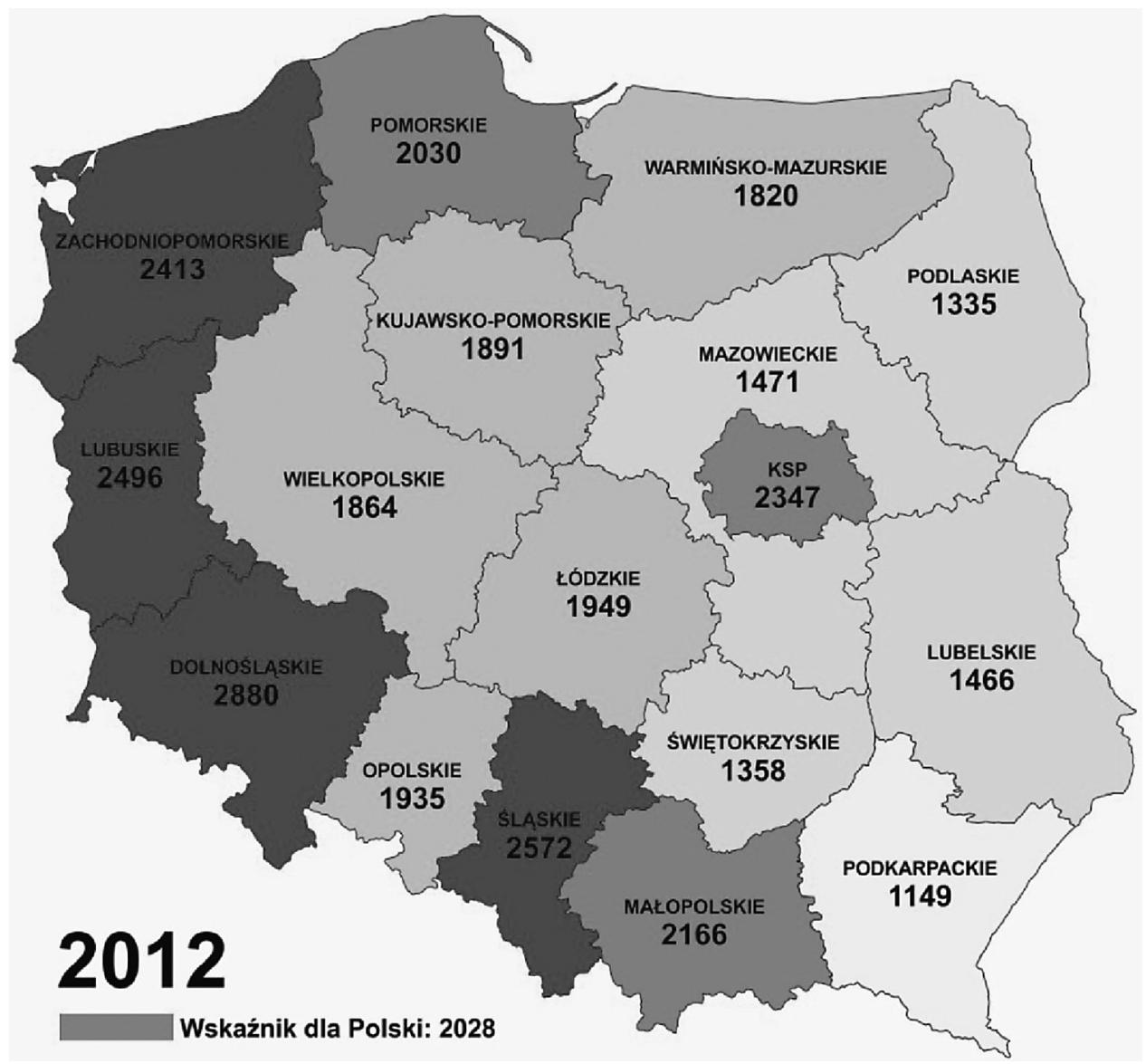

Źródlo: Raport o stanie bezpieczeństwa w Polsce w 2012 roku (2013), Warszawa, s. 25.

Przestępstwa o charakterze kryminalnym stanowią one 69,8\% ogólnej liczby przestępstw stwierdzonych. Po drugie, wyniki badań ankietowych CBOS (Raport, 2013: 16-17) z kwietnia 2012 r. oraz badania KGP w ramach PBP (Raport, 2013: 22-23) ze stycznia 2013 r. wskazują, że tego rodzaju przestępstw respondenci doświadczyli, albo tego rodzaju zagrożeń obawiają się. Po trzecie, ich dynamika kształtuje się na poziomie 98,4\%. Oznacza to tendencję spadkową w porównaniu do 2011 r. Czym ta tendencja jest spowodowana, nie wiadomo. Należy mieć na uwadze i pamiętać, że im mniejsze straty, tym większe prawdopodobieństwo, że pokrzywdzony faktu kradzieży nie zgłosi. W literaturze podaje się jeszcze inne przyczyny z powodu, których pokrzywdzeni rezygnują z powiadamiania o przestępstwach. Przy kradzieżach, których obawiają się Pola- 
cy (i ma to potwierdzenie w badaniach), wzrasta przykładowo liczba wykroczeń z art. 119 k.w. od 2008 r. W 2012 r. statystyki odnotowały 335130 wykroczeń z tego artykułu, czyli więcej o 2685 aniżeli rok wcześniej.

Podobnie jak kradzieże, można analizować inne kategorie przestępstw. Zaniżenie wartości czy świadome wypaczenie charakteru zdarzenia, też pozwala zmniejszać przestępczość. W znanej autorowi sytuacji, włamanie dokonane metodą na „pasówkę" umorzone zostało z braku znamion przestępstwa, przy przyjęciu kwalifikacji z art. 193 k.k. (naruszenie miru domowego). W śledztwie w związku z podejrzeniem naruszenia tajemnicy korespondencji np. prokurator konsekwentnie unikał przesłuchania nadawcy listu. Kiedy sąd uznał racje skarżącego oraz nakazał przeprowadzenie takiego dowodu, ściganie karne za ten czyn nie było możliwe, bo nastapiło przedawnienie karalności. To przestępstwo, podobnie jak dziewięć pozostałych w tym śledztwie, nie trafiło do policyjnych statystyk. Innym razem, zgłoszenie, że uczeń gimnazjum przyszedł do szkoły pod wpływem alkoholu ukierunkowane zostało na demoralizację, bez podjęcia próby ustalenia, kto dostarczył mu alkohol do spożycia. Te przykłady mają uzmysłowić, że w drodze pozaprawnych działań lub zaniechań (także z braku odpowiedniego poziomu wiedzy), też można kształtować przestępczość stwierdzoną.

Nawiązanie do danych statystycznych, odnoszących się do przestępczości, miało przede wszystkim pokazać możliwości w zakresie obserwacji tego zjawiska. System informatyczny policyjnej statystyki, pozwala jednak dokonywać innych jeszcze obserwacji bądź analiz, o czym była mowa już wcześniej. Wykorzystanie informacji zgromadzonych w różnych zbiorach, jest możliwe, jeżeli wcześniej zostały tam wprowadzone. Przykładowo operowanie liczbą przestępstw stwierdzonych było możliwe, dlatego, że jako przestępstwa znane trafiły do odpowiednich zbiorów. Jednakże przy ocenach przestępczości z wykorzystaniem danych statystycznych - na co zwraca uwagę Brunon Hołyst - należy pamiętać, że żadne zestawienie nie obejmuje wszystkich przestępstw rzeczywiście dokonanych (Hołyst, 1994: 65).

\section{PRZESTĘPCZOŚĆ NIEUJAWNIONA}

Policja informacje o możliwości popełnienia przestępstwa uzyskuje ze źródeł zewnętrznych oraz źródeł własnych (Hanusek, 2009: 63-71). Źródła wewnętrzne (własne), organizowane są przez organy ścigania w celach rozpoznawczych, wykrywczych i dowodowych, dla zapewnienia sobie dopływu informacji o osobach, faktach i zjawiskach (Gruza, Goc, Moszczyński, 2008: 31). Nadając tym informacjom wymiar praktyczny, przy odwołaniu się do danych statystycznych można powiedzieć, że policjanci zatrzymując 296175 sprawców na gorącym uczynku popełnienia przestępstwa w okresie 2012 roku $^{9}$, przyczynili się do ujawnienia jakiejś liczby przestępstw. Uwzględniając wysoki wskaźnik przestępstw, w których wykryto sprawcę ${ }^{10}$, hipotetycznie można

9 Źródło: KGP, statystyki dnia. Obliczenia własne.

10 Wcześniej była mowa, że 500539 podejrzanym udowodniono w ocenie policji popełnienie 759226 przestępstw. Statystycznemu podejrzanemu zatem udowodniono popełnienie 1,5168 przestępstwa. 
zakładać, że zatrzymania te przyczyniły się do wykrycia 449238 przestępstw. Przestępstwa te, po przeprowadzonych postępowaniach, trafią z czasem do policyjnej statystyki i nie można ich będzie uważać za przestępczość nieujawnioną. Kiedy to nastąpi? To zależy od czasu trwania postępowania mówiąc najprościej. Statystyka nie będzie wykazywała jednak przestępstwa stwierdzonego w miesiącu (roku) jego popełnienia, lecz w miesiącu (roku) jego wprowadzenia do odpowiedniego zbioru informatycznego. Inaczej mówiąc, zdarzenie noszące znamiona przestępstwa od chwili powzięcia wiadomości przez policję, do czasu jego rejestracji w systemie, przestępstwem statystycznie stwierdzonym nie jest. Aktualnie nie jest znana skala takiego statystycznego „poślizgu". To tworzy fałszywy statystyczny obraz przestępczości. Pojawia się inny jeszcze problem. Przestępczością nieujawnioną nazywa się także, „zbiór zdarzeń określanych jako przestępstwa, o których informacje nie dotarły do organów ścigania lub dotarły, lecz nie zostały przez nie zarejestrowane" (Błachut, Gaberle, Krajewski, 2007: 189). W literaturze kryminologicznej, dla określenia przestępczości nieujawnionej przyjęto się posługiwać pojęciem, tzw. ciemnej liczby przestępstw (ibidem: 227). Pojęcie to jest różnie rozumiane (Hanusek, 1979: 50-67). Różne też stosowane są techniki dla oszacowania rodzaju i rozmiarów interesującego nas przestępstwa. Wydaje się, iż rozumienie „ciemnej liczby”, jako różnicy pomiędzy liczbą rzeczywiście dokonanych przestępstw, a liczbą tych przestępstw, o których pierwsze informacje dotarły do organów ścigania (ibidem: 64), jest logicznie uzasadnione. Inaczej mówiąc, co jest nieznane - ciemne, co znane to - jasne. Także Brunon Hołyst przypadki ujawnionych przestępstw określa jasną liczbą (Hołyst, 1994: 65).

W raporcie, który stał się przyczynkiem do rozważań, wykorzystywane są dane liczbowe o znanej przestępczości, tak pod względem rodzaju, jak i rozmiarów. Nie znamy skali przestępstw rzeczywiście popełnionych, których przybliżoną wielkość poznajemy w drodze badań. Policja oraz inne organy odpowiedzialne za bezpieczeństwo, najwidoczniej nie są zainteresowane jakie przestępstwa i dlaczego nie są zgłaszane. Kiedy w latach 2006-2008 przeprowadzono badania, okazały się one bardzo interesujące oraz inspirujące do dalszych analiz i dociekań.

- W 2006 roku zgłoszono: 90\% kradzieży samochodów; 45\% rozbojów; 52,5\% pobić; $50,5 \%$ włamań do samochodów.

- W 2007 roku zgłoszono: 78,7\% kradzieży samochodów; 57,1\% rozbojów; 43,3\% pobić; $48,8 \%$ włamań do samochodów.

- W 2008 roku zgłoszono: 90,2\% kradzieży samochodów; 47,7\% rozbojów; 41\% pobić; 54,3\% włamań do samochodów (Raport, 2012: 28).

W tych samych badaniach zapytano osoby, które nie zgłosiły zdarzenia Policji, o powody takiej decyzji. Najczęściej wymienianym powodem była ocena, że zdarzenie nie było na tyle poważne, aby je zgłosić (w 2006 r. tak oceniało 46,8\% pytanych; w 2007 r. - 46,9\%, w 2008 r. - 48,4\%). Jako drugi powód respondenci wymieniali: „Policja i tak nie złapałaby sprawcy". W kolejnych latach tak odpowiedziało odpowiednio: $30,4 \%, 29,4 \%, 26,3 \%$ pytanych. Powodem trzecim była ocena, że „Policja nie zajęłaby się tą sprawą" (odpowiednio: 18,35\%, 19,1\%, 17,5\%). W następnej kolejności pojawiły się m.in. odpowiedzi: „chciałem uniknąć długich urzędowych procedur”, ,sprawca mimo złapania i tak nie zostałby ukarany”, „sam załatwiłem sprawę”, „obawiałem się zemsty”, „nie mam zaufania do Policji, wolę trzymać się z dala” (Raport, 2012: 28). 
Od tego czasu nikt podobnych badań nie robił. Stąd między innymi zainteresowanie przestępczością nieujawnioną.

Wszechstronne poznanie rzeczywistego poziomu zagrożeń, jest potrzebne do planowania i wdrażania konkretnych działań, zmierzających do podniesienia poziomu bezpieczeństwa. Znajomość ciemnej liczby przestępstw w konkretnych kategoriach potrzebna jest także po to, aby nie dochodziło do nietrafnych ocen stanu bezpieczeństwa (ibidem: 27). W ocenie autora, jest także inny obszar wymagający szerszego zainteresowania, także naukowego. Chodzi o wnikliwe poznanie skali i struktury oraz czynników wpływających na kształt wewnętrznej ciemniej liczby przestępstw, to jest takich, o których organy ścigania wiedzą bądź fakty są wysoce uprawdopodobnione, lecz nie wszczęto postępowań, toteż statystyki na ten temat milczą, nie odzwierciedlając tych zjawisk (Swół, 1998: 31; Swół, 2013: 638).

\section{STATYSTYKA JAKO NARZĘDZIE POZNANIA}

Statystyki kryminalne, o których wcześniej była mowa, służą różnym organom i różnym celom. W różnym zakresie zostają wykorzystywane, jako narzędzie pracy. Wydaje się, że uniwersalnej statystyki nie zachodzi potrzeba tworzyć. Najbogatsze w informacje są oczywiście policyjne zbiory danych, bo policjanci wykonują najszerszy zakres zadań związanych z zapewnieniem porządku i bezpieczeństwa publicznego. Policji w pierwszej kolejności powinno zależeć, aby informacje, którymi dysponuje, były jak najbardziej wiarygodne. Przez co będą wykazywać wysoki stopień przydatności. Praktyczna przydatność może przejawiać się między innymi tym, że uniemożliwiać będzie stosowania fikcyjnych kryteriów oceny pracy organów ścigania, a także będzie eksponować braki, przez co pozwoli na kształtowanie się właściwego spojrzenia na stan bezpieczeństwa. Przyjrzyjmy się jak to jest w praktyce, przy wykorzystaniu policyjnych statystyk.

W roku 2012 wskaźnik wykrywalności ogólnej przestępstw wyniósł 67,8\%. Wskaźnik ten nie precyzuje ile przestępstw wykryła policja. Wynika z tego, że w sytuacji, kiedy obywatel zatrzymał sprawcę na gorącym uczynku, statystyczny efekt przypisany jest policji. O wysokim wskaźniku zatrzymań na gorącym uczynku popełnienia przestępstwa lub bezpośrednio po jego popełnieniu była mowa. W 2012 r. według statystyk dnia zatrzymano 296175 osób, natomiast wszystkich podejrzanych było 500539 . Danych ze statystyk dnia jednak nie da się zweryfikować, gdyż nikt nie śledzi co się z tymi osobami potem stało. Po co zatem taka statystyka? Kiedy zainteresujemy się podejrzanymi i sposobem ich ustalenia, statystyki powiedzą nam, że: 888 sprawców zgłosiło się dobrowolnie; 124726 zostało wskazanych lub ujętych przez obywatela $(24,92 \%)$; 3586 zatrzymali pracownicy ochrony $(0,18 \%) ; 213207$ zatrzymanych zostało przez policjantów na gorącym uczynku lub w bezpośrednim pościgu $(42,6 \%)$, w wyniku czynności procesowych (dowodowych) 61658 podejrzanych (12,32\%), a 89887 na podstawie materiałów operacyjnych $(17,96 \%)$. Pozostałe ustalenia, też są zasługą policyjnych przedsięwzięć. Nie wynika to jasno ze statystyk. Wychodzi także na to, że w stosunku 129200 podejrzanych (25,81\%) policja nie musiała wykrywać, lecz tylko podejmować wobec nich ustalenia. Skuteczność policyjnych czynności $(74,2 \%)$ w ustalaniu podejrzanych, to bardzo wysoki udział. Kiedy bliżej przeanalizujemy ak- 
tywność obywateli, to okaże się, że w latach 2010-2012 liczba wskazanych sprawców lub liczba zatrzymanych spada z $26,4 \%$ do $24,9 \%$. Czym to jest spowodowane? Pozostawmy jednak to zainteresowanie do indywidualnych rozważań.

Zastanówmy się, czy wskaźniki dotyczące ustaleń w następstwie czynności procesowych (12,32\%) lub operacyjnych (17,96\%), można uznać za satysfakcjonujące. Odpowiedź wydaje się mieć istotne znaczenie przy ocenie kwalifikacji pracowniczych oraz ocenie poziomu podejmowanych czynności procesowych i operacyjnych. Co powinno być jednak punktem odniesienia przy formułowaniu takiej oceny?

Dane statystyczne zgromadzone w zbiorach policyjnych, poprawnie interpretowane są interesującym źródłem poznania, na innym jeszcze odcinku realizacji zadań. Weźmy dla przykładu sposób zakończenia postępowania, jako wskaźnik ocenny. Jako nieefektywnie zakończone, z pewnością należy zaliczyć postępowania umorzone z powodu niewykrycia sprawcy bądź sprawców. Było ich 36,5\% w stosunku do ogółu zakończonych. Efektywnie zakończone to takie, gdzie sprawcę wykryto, a wynik postępowania potwierdzony został w postępowaniu sądowym. Stanowiły one około 40,6\%. Statystyka policyjna wykazuje jeszcze inny możliwy sposób zakończenia postępowania, jak np. z przyczyn wyłączających ściganie (39 052) czy umorzenie wobec okoliczności, że podejrzany nie popełnił zarzuconego mu przestępstwa, a jednocześnie nie wykryto sprawcy. Takich postępowań było w 2012 roku 2134 (0,2078 ogółu zakończonych), ale ich liczba w latach 2010-2012 rośnie. W tych samym okresie, rośnie także liczba postępowań zwróconych w trybie nadzoru przez prokuratury (z 0,4981\% do 0,6231\%). W efekcie, uwidacznia się potrzeba zainteresowania się przyczyną takiego stanu rzeczy. Po drugie, uwidaczniają się ludzkie błędy. Po trzecie może obniżać się poziom pracy dochodzeniowo-śledczej, wreszcie po czwarte można dopatrywać się błędów w nadzorze służbowym.

O poziomie pracy, zwłaszcza operacyjnej, interesującej wskazówki udzielić nam mogą: liczba postępowań wszczętych na materiałach własnych, liczba postępowań podjętych z umorzenia bądź wartość odzyskanego i zabezpieczonego mienia u sprawców. Jeżeli chodzi o postępowania wszczynane na materiałach własnych policji, przede wszystkim zastanawia fakt braku w raporcie informacji o takich wszczęciach o przestępstwa kryminalne. Przy zwalczaniu przestępczości zorganizowanej podobnie. Być może to tylko przeoczenia autorów raportu, ale w oparciu o sprawozdanie CBŚ za 2012 rok trudno znaleźć taką informację również. Przy tej okazji jeszcze jedno odniesienie. Liczba zorganizowanych grup przestępczych rośnie z roku na rok. W 2012 r. w zainteresowaniu CBŚ i Straży Granicznej było ich 990 oraz 10052 członków tych grup. Świadczy to o lepszym rozpoznaniu operacyjnym, ale pozwala także zakładać, że w zakresie profilaktyki, to dowód na nieskuteczność działań. Nie wiadomo też, jak interpretować fakt, iż są zorganizowane grupy i związki mające na celu popełnienie przestępstwa, jest pokaźna grupa osób w nich uczestniczących, jest wreszcie przepis (art. 258 k.k.), a liczbę wszczęć postępowań z tego artykułu trudno ustalić.

W sprawach o przestępstwa przeciwko własności intelektualnej i przemysłowej, na materiałach własnych, wszczęto 1346 postępowań $(32,97 \%)$; z zakresu obrotu paliwami $1043(64,86 \%)$; w sprawach prania pieniędzy $17(12,14 \%)$; w sprawach o przestępstwa przeciwko wiarygodności dokumentów i obrotowi gospodarczemu 8399 (26,38\%); przy przestępstwach korupcyjnych 5159 (47,75\%); w sprawach przeciwko interesom finansowym UE 208 postępowań (43,06\%). Jakie efekty w ujawnianiu prze- 
stępstw mają instytucje kontrolne przedsiębiorców, samorządów i innych wyspecjalizowanych organów państwa?

W skali roku, podjęto z umorzenia łącznie 11340 postępowań, tj. 1,1045\% w stosunku do ogółu. Zatem podjęto co trzydzieste postępowanie umorzone wcześniej z powodu niewykrycia sprawcy. To też o czymś świadczy.

Straty spowodowane działalnością przestępczą, biorąc pod uwagę rejestrację policyjną w 2012 roku oszacowano na 6441888013 zł. Wartość mienia odzyskanego oszacowano na 283736348 zł, a zabezpieczonego na 376752152 zł. Wartość odzyskanego i zabezpieczonego mienia to $1,02 \%$ strat. Gdyby brać pod uwagę rok 2011, to straty spowodowane działalnością przestępczą były niższe, a wartość odzyskanego i zabezpieczonego mienia była wyższa o 8646170 zł niż rok później. Gdyby przyjąć procentowy wskaźnik, to wartość odzyskanego i zabezpieczonego mienia wynosi 1,33\% strat spowodowanych działalnością przestępczą.

Najważniejszym wskaźnikiem służącym do oceny skuteczności państwa w dziedzinie zapewnienia bezpieczeństwa i porządku publicznego jest poczucie bezpieczeństwa obywateli. W artykule przedstawiono wycinek takich działań, ponieważ bezpieczeństwo to pojęcie wieloznaczne, a zadanie w imieniu państwa realizuje wiele podmiotów. W artykule tym najwięcej uwagi poświęcono Policji, bo ta formacja realizuje najwięcej zadań określonych ustawą o Policji i innymi jeszcze ustawami. Poczucie bezpieczeństwa, jak to zostało wykazane, to stan emocjonalny, na który ma wpływ prawidłowe wypełnianie obowiązków służbowych. Jak wynika z zaprezentowanych wcześniej badań, pomiaru poczucia bezpieczeństwa Polaków nie da się dokonać, przytaczając nawet najkorzystniejsze wskaźniki. Dlatego wszelkie dane zawarte w raporcie z 2012 roku (za wyjątkiem rozdziału drugiego), jawią się, jako dodatek do źle dobranego garnituru. Statystyki nie można czytać, lecz należy ją interpretować, na tle innych wcześniej przyjętych wskaźników. Ograniczając tylko tę myśl, do przykładu z wartością zabezpieczonego mienia, przed wyprowadzeniem wniosku, jedno odniesienie. W podobnym raporcie za 2010 r. we wniosku pkt 6. napisano: „Z uwagi na fakt, że podstawowym motywem działalności przestępczej, w tym tworzenia i funkcjonowania zorganizowanych grup przestępczych, jest uzyskiwanie korzyści majątkowych, niezwykle dotkliwą dla przestępców metodą zwalczania przestępczości jest skuteczne pozbawianie ich mienia”. A teraz do meritum. Statystyka mówi o zdarzeniach rzeczywistych, a wnioski z niej wynikające o potrzebach. Potrzeby poszukiwania możliwości efektywniejszych działań Policji, nie moga przysłonić optymistyczne wskaźniki poczucia bezpieczeństwa. Raport, który stał się inspiracją do poruszenia tej problematyki, chyba zbyt optymistycznie przedstawiał otaczającą nas rzeczywistość.

\section{Bibliografia}

Bezpieczeństwo. Aspekty polskie i międzynarodowe (2012), (red.) H. Lisiak, Poznań.

Błachut J., Gaberle A., Krajewski K. (2007), Kryminologia, Gdańsk. 
Borzęcki M. (2000), Statystyka a bicie piany, „Gazeta Policyjna”, nr 3.

Choromańska A. (2008), ,,Temida” w stużbie policji - refleksje na temat statystyki policyjnej, „Policja", nr 3.

Czapska J., Wójcikiewicz J. (1999), Policja w społeczeństwie obywatelskim, Kraków.

Fehler W., Dziubek I. T. (2010), Bezpieczeństwo Wewnętrzne Państwa. Ekspertyza przygotowana na zlecenie Ministerstwa Rozwoju Regionalnego, Warszawa.

Gruza E., Goc M., Moszczyński J. (2008), Kryminalistyka - czyli rzecz o metodach śledczych, Warszawa.

Hanusek T. (1979), Zarys kryminalistycznej teorii wykrywania, część 1, Warszawa.

Hanusek T. (2009), Kryminalistyka. Zarys wykładu, Warszawa.

Hołyst B. (1979), Kryminologia, Warszawa.

Hołyst B. (1994), Kryminologia, Warszawa.

Hołyst B. (2010), Kryminalistyka, Warszawa.

Horoszowski P. (1965), Kryminologia, Warszawa.

Jasiński A. (2013), Architektura w czasach terroryzmu. Miasto - Przestrzeń publiczna - Budynek, Warszawa.

Kokoszka A. (2013), Patologiczny lęk i strach, http://www.mp.pl/poz/psychiatria/zaburzenia_lekowe/show.html?id=89844.

Koziej S. (2011), Bezpieczeństwo: istota, podstawowe kategorie i historyczna ewolucja, „Bezpieczeństwo Narodowe", nr 18.

Misiuk A. (2011), Administracja porzqdku i bezpieczeństwa publicznego. Zagadnienia prawno-ustrojowe, Warszawa.

Pieprzny S. (2011), Policja. Organizacja i funkcjonowanie, Warszawa.

Pieprzny S. (2012), Administracja bezpieczeństwa i porzadku publicznego, Rzeszów.

Pokruszyński W. (2011), Filozoficzne aspekty bezpieczeństwa, Józefów.

Raport o stanie bezpieczeństwa w Polsce w 2011 roku (2012), Warszawa.

Raport o stanie bezpieczeństwa w Polsce w 2012 roku (2013), Warszawa.

Serafin T., Parszowski S. (2011), Bezpieczeństwo społeczności lokalnych. Programy prewencyjne w systemie bezpieczeństwa, Warszawa.

Skorupka S. (1985), Stownik frazeologiczny języka polskiego, Warszawa.

Sławik K. (1978), Kilka uwag o roli obecnej statystyki kryminalnej, „Problemy Kryminalistyki”, nr 135.

Sławik K. (2011), Zarys systemu prawa policyjnego, Warszawa.

Stownik języka polskiego, http://sjp.pl/operacjonalizacja, 21.12.2013.

Stownik poprawnej polszczyzny PWN (1980), Warszawa.

Słownik współczesny języka polskiego (2001), tom 1, Warszawa.

Swół J. (1998), Kulawa statystyka przestępczości, „Przegląd Policyjny”, nr 1(49).

Swół J. (1999), O stanie iluzji, „Prawo i Życie”, nr 13(1766).

Swół J. (2012), Bezpieczeństwo w Polsce w statystykach z 2011 roku, „e-Terroryzm.pl”, nr 10.

Swół J. (2012), Bezpieczeństwo w Polsce w statystykach z 2011 roku. Krytycznie o raporcie nt. bezpieczeństwa w Polsce, „e-Terroryzm.pl”, nr 12.

Swół J. (2012), Bezpieczeństwo w Polsce w statystykach z 2011 roku. Część II, ,e-Terroryzm.pl”, nr 10.

Swół J. (2012), Prawo jest dla każdego. Nieznajomość prawa szkodzi, „e-Terroryzm.pl”, nr 9. 
Swół J. (2013), Statystyczne bezpieczeństwo w Polsce. Kilka uwag i refleksji, w: Bezpieczeństwo w procesach globalizacji - dziś i jutro, tom I, (red.) Z. Grzywna, Katowice.

Szymik J. (2013), Bezpieczeństwo w komunikacji lotniczej, w: Bezpieczeństwo w procesach globalizacji - dziś i jutro, tom I, (red.) Z. Grzywna, WSZM i JO, Katowice.

Urban A. (2011), Bezpieczeństwo społeczności lokalnych, Warszawa.

Ustawa z 29 czerwca 1995 r. o statystyce publicznej (2012), Dz. U. Nr 0, poz. 591 ze zm.

Ustawa z dnia 24 maja 2013 r. o środkach przymusu bezpośredniego i broni palnej (2013), Dz. U. $\mathrm{Nr} 0$, poz. 628 ze zm.

Wolanin J. (2005), Zarys teorii bezpieczeństwa obywateli. Ochrona ludności na czas pokoju, Warszawa.

\title{
STRESZCZENIE
}

Zagadnienie bezpieczeństwa mimo krótkiego rozwoju nauki o nim w Polsce, doczekało się stosunkowo bogatego dorobku naukowego. Autor zainteresował się jego stanem, po ukazaniu się kolejnego raportu Ministerstwa Spraw Wewnętrznych omawiającego stan bezpieczeństwa w 2012 roku. W artykule znajdziemy krótkie nawiązanie do wieloznaczności pojęcia „,bezpieczeństwo" oraz problemów z jego obiektywną oceną. Autor odwołując się do literatury, przybliża czynniki mające wpływ na poczucie bezpieczeństwa. Przy wykorzystaniu danych statystycznych, podejmowana jest próba ukazania efektywności działań niektórych służb policyjnych. W treści artykułu stawiane są pytania, na które autor najczęściej nie udziela odpowiedzi, inspirując tym samym czytelnika, do własnych przemyśleń i formułowania ocen. Odwołując się natomiast do danych i wskaźników statystycznych, stara się wykazać jak wieloznacznie można i należy interpretować dane statystyczne. W artykule znajdziemy uzasadnienie dla tezy, że statystyka nie powinna być celem, a narzędziem służącym przybliżeniu do prawdy w zakresie zagrożeń kryminalnych. Z tego narzędzia należy korzystać jednak w sposób umiejętny.

\section{STATISTICAL SECURITY IN POLAND}

\begin{abstract}
The issue of safety in spite of a short study of the development in Poland, come to see the relatively rich scientific achievements. The author became interested in the state, after the publication of the next report of the Ministry of Internal Affairs discussing the security situation in 2012. In this article you will find a brief formation to the ambiguity of the concept of ,safety" and the problems of its objective evaluation. By referring to the literature introduces factors affecting the sense of safety. Using statistical data, it attempts to release some of the effectiveness of the police service. In the article questions are asked, to which the author frequently does not respond, thus inspiring the reader to formulate their own thoughts and evaluations. Referring while the data and statistical indicators, seeks to show how ambiguous it can be. In this article you will find a justification for the claim that the statistics should not be a goal, but to approximate the truth in the field of criminal threats. This tool should be used in a skilful way.
\end{abstract}

